\title{
GEOKIMIA BATUAN INDUK HIDROKARBON FORMASI CINAMBO DI DAERAH SUMEDANG, JAWA BARAT
}

\section{GEOCHEMISTRY OF HYDROCARBON SOURCE ROCK OF THE CINAMBO FORMATION IN THE SUMEDANG AREA, WEST JAVA}

\author{
Praptisih \\ Pusat Penelitian Geoteknologi LIPI, Bandung \\ praptie3103@yahoo.com
}

\begin{abstract}
ABSTRAK
Penelitian geokimia batulempung telah dilakukan pada Formasi Cinambo di wilayah Kabupaten Sumedang, dengan tujuan untuk mengetahui karakter batuan induk dan biomarker ekstrak batuan serta hubungannya dengan rembesan minyak di daerah Majalengka. Metode yang dilakukan adalah penelitian lapangan dan analisis laboratorium yang meliputi analisis Total Organic Carbon (TOC), pirolisis Rock Eval dan Gas Chromatography Mass Spectrometry (GCMS). Penelitian lapangan meliputi pengamatan litostratigrafi Formasi Cinambo pada Sungai Cinambo dan Cisaar serta pengambilan percontoh untuk analisis laboratorium. Hasil analisis dari 16 percontoh batulempung Formasi Cinambo menunjukkan nilai TOC $0,32-1,47 \%$ yang berpotensi rendah hingga baik untuk membentuk hidrokarbon. Material organik di daerah penelitian termasuk dalam kerogen tipe III, berdasarkan diagram TOC vs Hydrogen Index (HI). Tingkat kematangan 4 percontoh mengindikasikan kondisi belum matang (immature), 6 percontoh termasuk matang dan 6 percontoh lainnya tidak terdeteksi. Berdasarkan nilai HI, yaitu 2-90, dapat menghasilkan gas dengan kuantitas kecil. Hasil biomarker ekstrak batuan Formasi Cinambo menunjukkan tidak ada korelasi positif dengan rembesan minyak di daerah Majalengka.
\end{abstract}

Kata kunci: geokimia, batuan induk, hidrokarbon, biomarker, Formasi Cinambo

\section{ABSTRACT}

Research on geochemical characteristics of the Cinambo Formation claystone was carried out in the Sumedang area. The purpose of this research is to understand the character of hydrocarbon source rock and biomarker of rock extract samples in association with oil seepage in the Majalengka area. Methods are field and laboratory research, including Total Organic Carbon (TOC) analysis, Rock Eval Pyrolysis and Gas Chromatography Mass Spectrometry (GCMS). The field research includes lithostratigraphy of the Cinambo Formation in the Cinambo and Cisaar Rivers, collecting rock samples for laboratory analyses purposes. The results of 16 samples of claystone from the Cinambo Formation show TOC value about $0.32-1.47 \%$, which has a low potential to well form hydrocarbons. Organic materials in the studied area include type III kerogen based on TOC vs Hydrogen Index (HI) diagrams. The maturity level of 4 samples is immature, 6 samples are mature and 6 more are undetected. Based on $\mathrm{HI}$ value that is 2-90, this can produce gas with small quantity. The results of biomarker of rock extract of the Cinambo Formation indicate no positive correlation with oil seepage in the Majalengka area.

Keywords: geochemistry, source rock, hydrocarbon, biomarker, Cinambo Formation 


\section{PENDAHULUAN}

Dijumpainya rembesan minyak bumi di daerah Sukamurni, wilayah Kabupaten Majalengka mengindikasikan bahwa terdapat batuan induk yang dapat menggenerasi minyak bumi. Rembesan minyak tersebut muncul pada endapan vulkanik muda. Permasalahannya adalah batuan induk mana yang menjadi asal rembesan minyak tersebut. Secara stratigrafi kedudukan batuan induk berada di bawah batuan vulkanik muda (Praptisih, 2016). Berdasarkan dugaan sementara, batuan induk tersebut adalah batuan yang termasuk dalam Formasi Cinambo yang secara stratigrafi kedudukannya lebih tua dari batuan vulkanik. Formasi Cinambo di daerah Sumedang tersingkap baik dan merupakan lokasi tipe dari Formasi Cinambo yang berjarak sekitar $5 \mathrm{~km}$ dengan rembesan minyak di Majalengka. Untuk itu dilakukan penelitian yang bertujuan mengetahui karakter geokimia batuan induk dan biomarker ekstrak batuan di daerah Sumedang serta hubungannya dengan rembesan minyak bumi di daerah Majalengka. Penelitian karakteristik geokimia batulempung dilakukan pada Formasi Cinambo di lintasan Sungai Cinambo dan Sungai Cisaar di daerah Sumedang. Penelitian geokimia rembesan minyak bumi telah dilakukan oleh para peneliti terdahulu diantaranya Hidayat dan Fatimah, 2007; Subroto dkk, 2007; Pramono, W. dan Amijaya, H., 2008; Praptisih, 2016; Praptisih dan Kamtono, 2016; Panggabean \& Heryanto, 2009.

\section{METODOLOGI}

Penelitian ini dimulai dengan penelusuran pustaka yang berkaitan dengan cekungan sedimen yang telah terbukti mengandung hidrokarbon. Selanjutnya pengamatan litostratigrafi di lapangan dan pengambilan percontoh batuan untuk analisis laboratorium. Penelitian di laboratorium meliputi analisis geokimia batulempung yang diambil pada Formasi Cinambo di daerah Sumedang. Analisis geokimia yang dilakukan adalah kandungan TOC (Total
Organic Carbon), pirolisis rock eval dan GCMS (Gas Chromatography Mass Spectrometry) ekstrak batuan.

\section{GEOLOGI}

Daerah penelitian termasuk dalam Peta Geologi lembar Arjowinangun berskala 1:100.000 yang telah dipetakan oleh Djuri, (1995). Stratigrafinya disusun berdasarkan urutan dari tua ke muda, yaitu Formasi Cinambo, Formasi Halang, Subang, Formasi Kaliwungu dan Formasi Citalang yang ditutupi oleh endapan vulkanik Plistosen (Satuan Breksi terlipat) dan endapan batuan gunung api Kuarter Formasi Cinambo Anggota Batupasir disusun oleh batupasir grewake, batupasir gampingan, tufa, batulempung dan batulanau. Formasi Cinambo Anggota Serpih disusun oleh batulempung dengan selingan batupasir, batupasir gampingan dan batupasir tufaan. Formasi Halang anggota bawah disusun oleh breksi gunungapi andesitis dan basaltis, tufa, batulempung konglomerat. Formasi Halang anggota atas disusun oleh batupasir tufa, batulempung konglomerat. Formasi Subang disusun oleh batulempung mengandung lapisan batugamping, abuabu tua. Formasi Kaliwungu disusun oleh batulempung dengan sisipan batupasir tufaan, konglomerat, kadang kala dijumpai batupasir gampingan dan batugamping. Formasi Citalang disusun oleh batupasir tufaan, coklat muda, batulempung tufaan, konglomerat, kadang dijumpai batupasir tufaan. Batuan vulkanik breksi terlipat disusun oleh breksi vulkanik dengan fragmen berkomposisi andesitis, breksi tufaan, batulempung tufaan dan grewake. Endapan gunung api Kuarter terdiri dari breksi lava, lahar dan tufa.

Kemungkinan Formasi Subang juga bisa diduga sebagai batuan induk, tetapi pada penelitian ini fokus pada Formasi Cinambo karena diambil Formasi yang berumur paling tua dan memenuhi syarat sebagai batuan induk, yaitu batuan yang berbutir halus dan berwarna gelap yaitu batulempung pada Formasi Cinambo. 
Struktur yang berkembang di daerah ini erupa lipatan dan sesar. Struktur Lipatan terdiri dari sinklin dan antiklin yang melibatkan batuan-batuan berumur Miosen dengan sumbu lipatan berarah baratlauttenggara yang dipotong oleh sesar mendatar utara baratlaut-selatan tenggara (Gambar 1).

\section{HASIL DAN PEMBAHASAN}

\section{HASIL}

Sebanyak 16 percontoh batulempung Formasi Cinambo pada lintasan Sungai Cinambo (3 percontoh) dan Sungai Cisaar (13 percontoh) di daerah Sumedang dianalisis TOC dan pirolisis rock eval (Gambar 2) dan hasilnya tersaji pada Tabel 1. Untuk analisis GCMS terhadap ekstrak batuan dilakukan pada 2 percontoh batulempung Formasi Cinambo dari lintasan Sungai Cinambo (1 percontoh) dan Sungai Cisaar (1 percontoh) (Gambar 2).

\section{PEMBAHASAN}

\section{Tipe dan kualitas material organik}

Batuan induk Formasi Cinambo di daerah Sumedang mempunyai nilai TOC 0,32$1,47 \%$, dan berpotensi rendah hingga baik dalam membentuk hidrokarbon (Douglas W. Waples, 1985). Nilai HI di daerah penelitian berkisar antara 2-90 mg $\mathrm{HC} / \mathrm{g}$. Nilai TOC nya termasuk relatif rendah dan batuan induk ini diperkirakan mempunyai potensi membentuk gas (Douglas W. Waples, 1985). Faktor penting yang mempengaruhi kapasitas batuan induk untuk menggenerasi minyak bumi adalah banyaknya hidrogen dalam kerogen (Hunt, 1979). Klasifikasi berdasarkan HI (Baskin, 1997) adalah sebagai berikut :

1) $<100 \mathrm{mgHC} / \mathrm{g}$ TOC gas prone,

2) 100 - $200 \mathrm{mgHC} / \mathrm{g}$ TOC gas dan oil prone, dan

3) $>300 \mathrm{mgHC} / \mathrm{g}$ TOC oil prone.

Daerah penelitian termasuk dalam kelompok gas prone berdasarkan klasifikasi Baskin, (1997). Hasil plot 9 percontoh di daerah penelitian pada diagram $\mathrm{HI}$ vs $\mathrm{T}$ max (Gambar 3), menunjukkan bahwa material organik percontoh tersebut termasuk kerogen tipe III, mengacu pada Mukhopadhyay, dkk, (1995).

\section{Tingkat Kematangan}

Kematangan material organik berdasarkan nilai T max yang berkisar antara $391-446^{\circ} \mathrm{C}$ (Tabel 1), sebanyak 5 percontoh dalam kondisi belum matang, 6 percontoh tidak terdeteksi $\mathrm{T}$ max-nya dan 5 percontoh lainnya termasuk matang dengan nilai $\mathrm{T}$ max berkisar $437-446^{\circ} \mathrm{C}$.

\section{Kekayaan material Organik}

Diagram kandungan hidrokarbon (PY) vs TOC (Gambar 4) menunjukkan bahwa 7 percontoh dari Formasi Cinambo di daerah penelitian termasuk kategori miskin dengan kandungan Hidrokarbon (PY) berkisar antara 0,06-1,57 kg/ton dan kisaran kandungan karbon (TOC) $0,43-1,47 \%$ dari 7 percontoh batuan yang dianalisis dan diplot dalam diagram PY vs TOC (Gambar 4), menempati daerah gas prone (Rad, 1984). 


\section{MAKALAH ILMIAH}

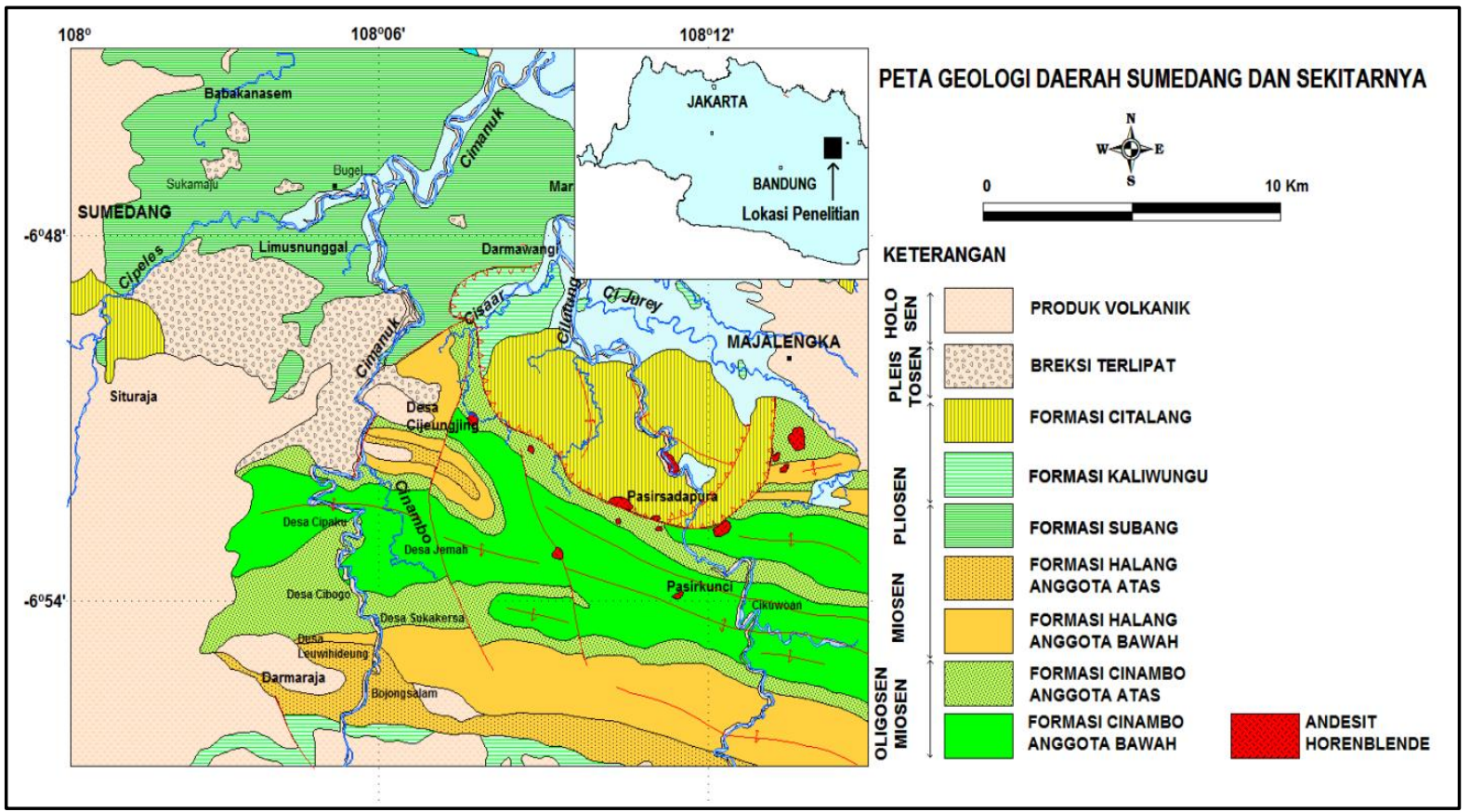

Gambar 1. Peta Geologi daerah Sumedang dan sekitarnya (Djuri, 1995)

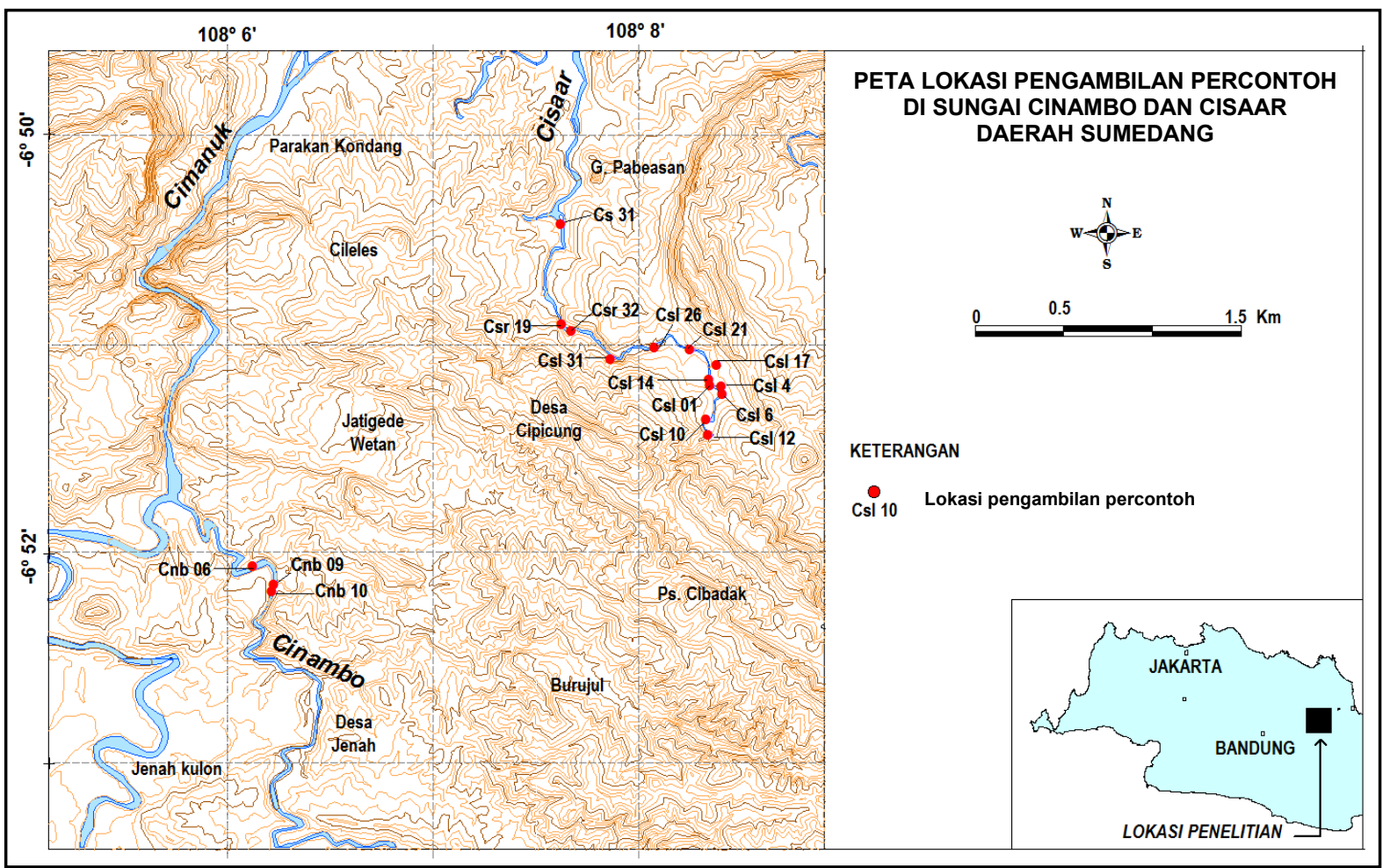

Gambar 2. Peta lokasi pengambilan percontoh batulempung Formasi Cinambo di daerah penelitian 


\section{MAKALAH ILMIAH}

Tabel 1. TOC dan pirolisis rock eval daerah Sumedang

\begin{tabular}{|c|c|c|c|c|c|c|c|c|c|c|c|}
\hline \multirow[t]{2}{*}{ No } & \multirow[t]{2}{*}{ Percontoh } & \multirow[t]{2}{*}{ Litologi } & \multirow{2}{*}{$\begin{array}{c}\text { TOC } \\
(\%)\end{array}$} & S1 & $\mathrm{S} 2$ & S3 & PY & \multirow[t]{2}{*}{$\mathrm{PI}$} & \multirow{2}{*}{$\begin{array}{c}\text { Tmax } \\
\left({ }^{\circ} \mathrm{C}\right)\end{array}$} & \multirow[t]{2}{*}{$\mathrm{HI}$} & \multirow[t]{2}{*}{$\mathrm{Ol}$} \\
\hline & & & & \multicolumn{4}{|c|}{$\mathrm{Mg} / \mathrm{g}$} & & & & \\
\hline 1 & CNB 6 & Batulempung & 1,03 & 0,03 & 0,53 & 0,06 & 0,56 & 0,05 & 430 & 51 & 6 \\
\hline 2 & CNB 9 & Batulempung & 0,58 & 0,02 & 0,23 & 0,06 & 0,25 & 0,08 & 423 & 40 & 10 \\
\hline 3 & CNB 10 & Batulempung & 0,47 & 0,01 & 0,01 & 0,12 & 0,02 & 0,50 & 429 & 2 & 26 \\
\hline 4 & CS 31 & Batulempung & 0,45 & 0,02 & 0,00 & 0,05 & 0,02 & 1,00 & - & 0 & 11 \\
\hline 5 & CSR 19 & Batulempung & 0,55 & 0,05 & 0,00 & 0,07 & 0,05 & 1,00 & - & 0 & 13 \\
\hline 6 & CSR 32 & Batulempung & 0,46 & 0,02 & 0,02 & 0,06 & 0,04 & 0,50 & 391 & 4 & 13 \\
\hline 7 & CSL 1 & Batulempung & 1,19 & 0,23 & 0,87 & 0,21 & 1,10 & 0,21 & 444 & 73 & 18 \\
\hline 8 & CSL 4 & Batulempung & 1,14 & 0,29 & 0,76 & 0,20 & 1,05 & 0,28 & 446 & 67 & 18 \\
\hline 9 & CSL 6 & Batulempung & 1,30 & 0,33 & 1,16 & 0,03 & 1,49 & 0,22 & 445 & 89 & 2 \\
\hline 10 & CSL 10 & Batulempung & 0,43 & 0,06 & 0,00 & 0,03 & 0,06 & 1,00 & - & 0 & 7 \\
\hline 11 & CSL 12 & Batulempung & 0,32 & 0,00 & 0,00 & 0,00 & 0,00 & - & - & 0 & 0 \\
\hline 12 & CSL 14 & Batulempung & 1,47 & 0,25 & 1,32 & 0,30 & 1,57 & 0,16 & 446 & 90 & 20 \\
\hline 13 & CSL 17 & Batulempung & 0,67 & 0,03 & 0,00 & 0,05 & 0,03 & 1,00 & - & 0 & 7 \\
\hline 14 & CSL 21 & Batulempung & 0,68 & 0,12 & 0,38 & 0,09 & 0,50 & 0,24 & 437 & 56 & 13 \\
\hline 15 & CSL 26 & Batulempung & 0,42 & 0,02 & 0,00 & 0,04 & 0,02 & 1,00 & - & 0 & 9 \\
\hline 16 & CSL 31 & Batulempung & 0,82 & 0,03 & 0,06 & 0,04 & 0,09 & 0,33 & 434 & 7 & 5 \\
\hline
\end{tabular}

Keterangan:

$\mathrm{S}_{1}=$ Hidrokarbon bebas

Indek Produksi=Rasio Transformasi $=\mathrm{S}_{1} /\left(\mathrm{S}_{1}+\mathrm{S}_{2}\right)$

Pirolisis menggunakan alat Rock Eval II,

TOC menggunalkan alat LECO
$\mathrm{S}_{2}=$ Hidrokarbon pirolisis

T maks =Temperatur maksimum

Indek Hidrogen $=\left(\mathrm{S}_{2} / \mathrm{TOC}\right) \times 100$
$\mathrm{S}_{3}=\mathrm{CO}_{2}$ organik Indek Oksigen=(S3/ TOC) $\times 100$

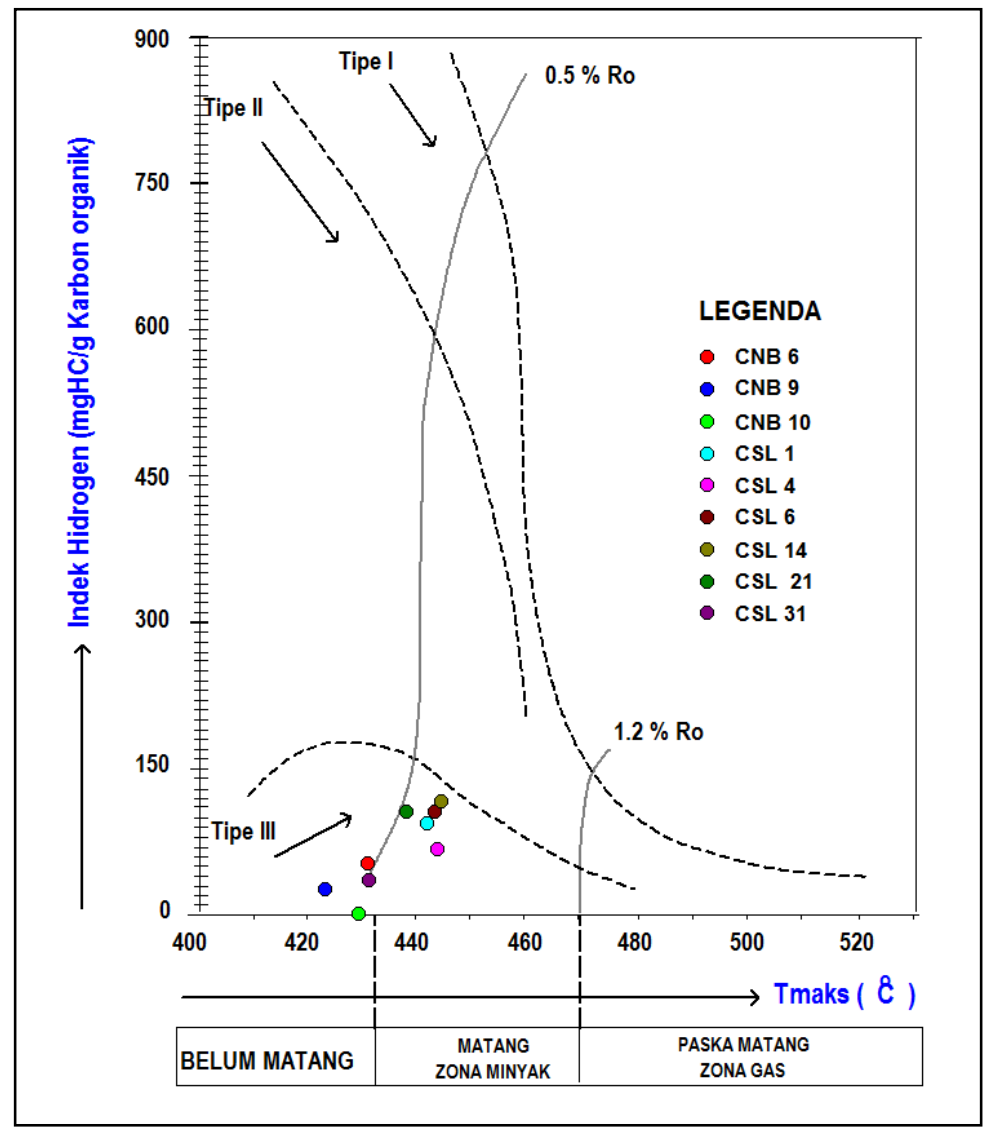

Gambar 3. Diagram percontoh Formasi Cinambo pada diagram $T_{\max }$ terhadap indeks hidrogen yang memperlihatkan tipe kerogen dan tingkat kematangan

(Mukhopadhyay, dkk. ,1995) 


\section{MAKALAH ILMIAH}

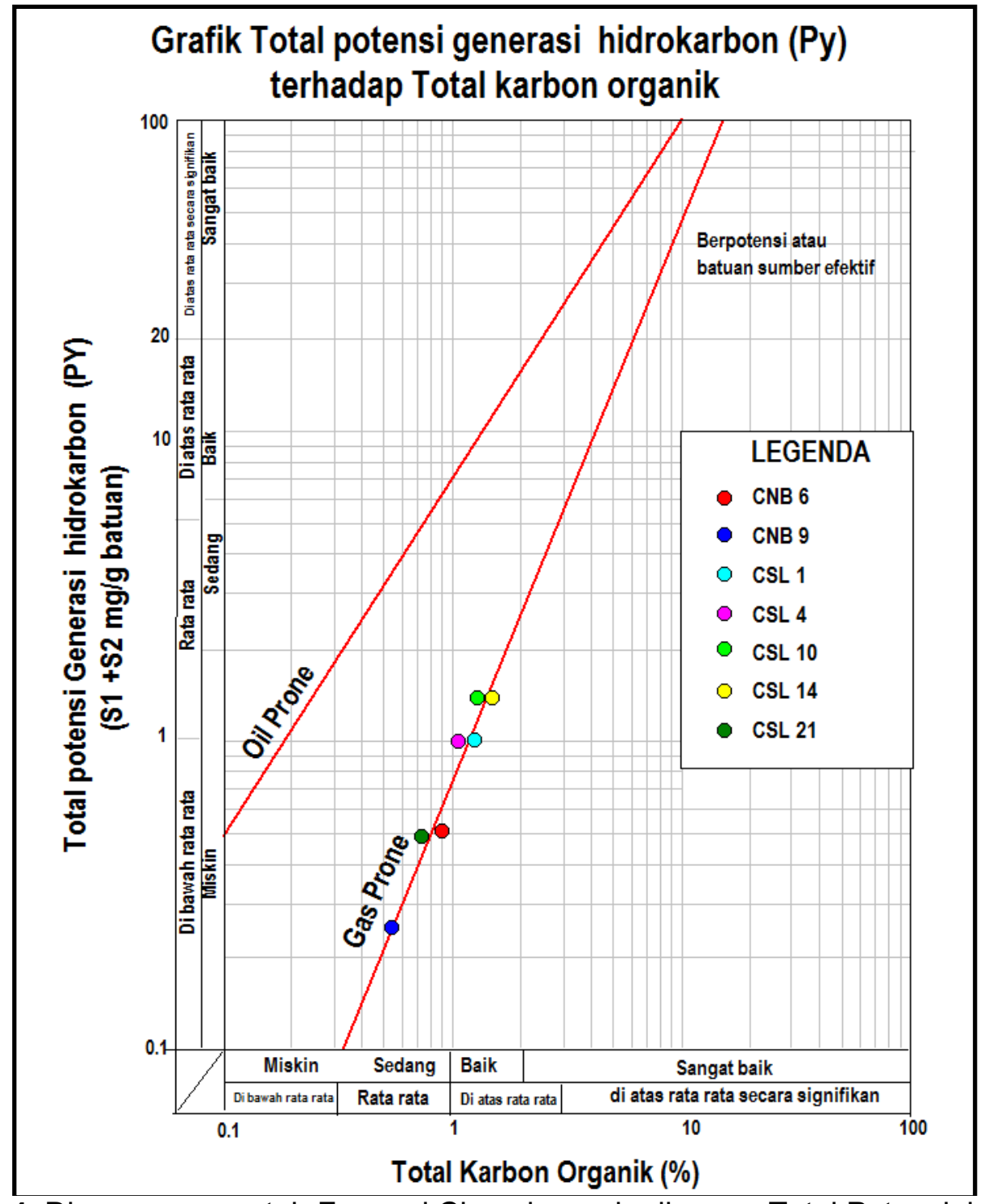

Gambar 4. Diagram percontoh Formasi Cinambo pada diagram Total Potensial generasi Hidrokarbon terhadap Total Karbon Organik (TOC) terhadap Total Generation Potential (PY) (Rad, 1984)

\section{Analisis GCMS}

Analisis GCMS pada ekstrak batuan Formasi Cinambo daerah Sumedang diambil dari Sungai Cinambo, yaitu percontoh CNB 06 dan Sungai Cisaar, yaitu percontoh CSL 12. Analisis tersebut dilakukan bersamaan dengan analisis TOC dan pirolisis rock eval. M/Z 191 (Gambar $5 \mathrm{~A})$ menunjukkan bahwa ekstrak batuan mempunyai distribusi terpana trisiklik dan tetrasiklik yang jumlah atom karbonnya berkisar dari C19 sampai C26 (Senyawa AI pada m/z 191). Jumlah C23 (Puncak "F") senyawa trisiklik relatif lebih tinggi dibanding senyawa C19 dan C20 (Puncak "A-C"), merupakan suatu indikasi fasies yang sumbernya berasal dari material alga (ganggang) (Price, et.al, 1987). Fragmentogram Massa dari biomarker Sterana (m/z 217) (Gambar 5B) menunjukkan distribusi normal memperlihatkan sterana C27 sterana $(54,32-55,83)$ mempunyai proporsi yang lebih besar dari C29 sterana $(25,48-26,57)$, merupakan bukti kuat bahwa material organiknya berasal dari alga (ganggang). 
Dari perhitungan persentase luas jumlah karbon tersebut dan diplot ke diagram segitiga Huang dan Meinschein's, 1979 (Waples dan Machihara, 1991) (Gambar 6) diperkirakan diendapkan pada lingkungan laut terbuka atau danau dalam (open marine or deep lacustrine).

Tingkat kematangan dilihat dari perhitungan rasio TM/Ts 0,16-0,18 menunjukkan biomarker matang. Rasio
22S/22R pada $\mathrm{C} 31 \mathrm{H}$ dan $\mathrm{C} 32 \mathrm{H}$ diperoleh harga $1,19-1,40$ dan 1,37-1,44. Proporsi 22R, 22S menunjukkan biomarker hampir matang dan matang. Dari data GCMS untuk fraksi aromat, yaitu Indeks metilfenantrena $(\mathrm{MPI}-1=0,32-1,09)$ dihitung dari distribusi fenantrena $(\mathrm{m} / \mathrm{z} 178)$ dan metilfenantrena ( $\mathrm{m} / \mathrm{z} 192)$ menunjukkan bahwa percontoh ekstrak batuan tergenerasi pada tingkat kematangan hampir matang dan matang.
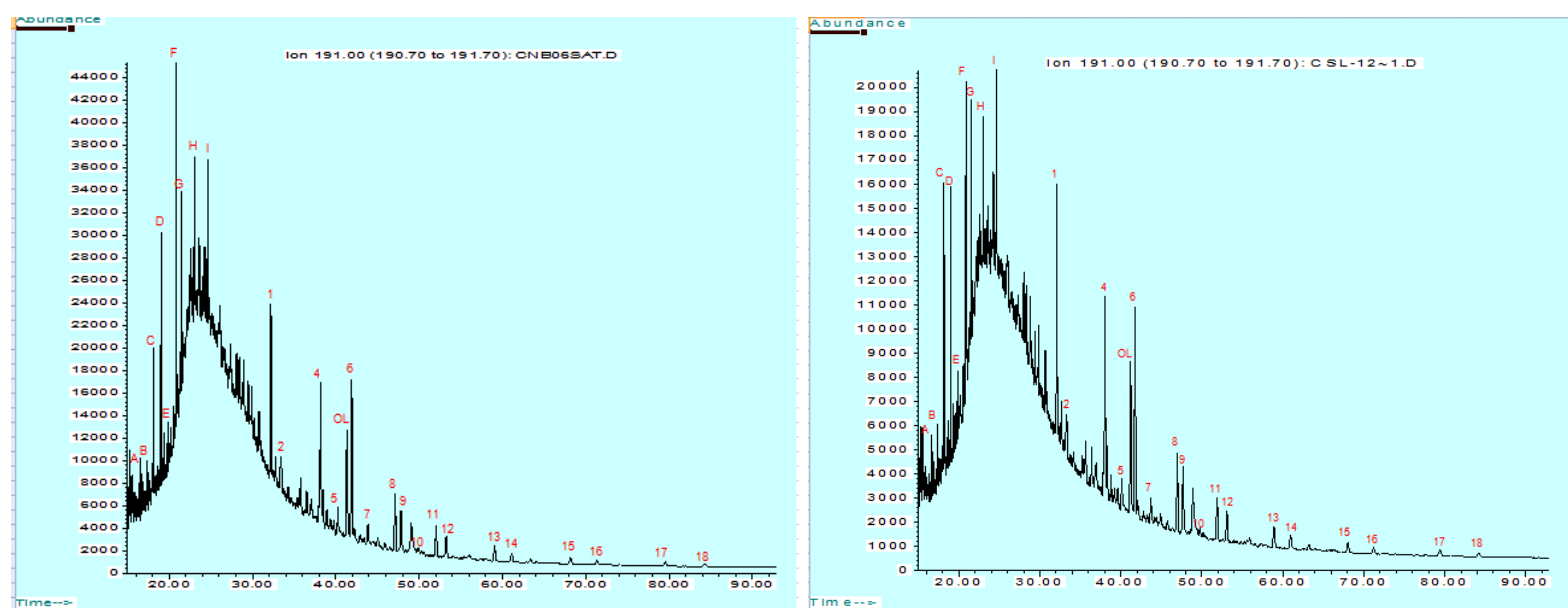

Gambar 5A. Diagram Fragmentogram Massa dari biomarker Steranana (m/z 191) pada Formasi Cinambo daerah Sumedang
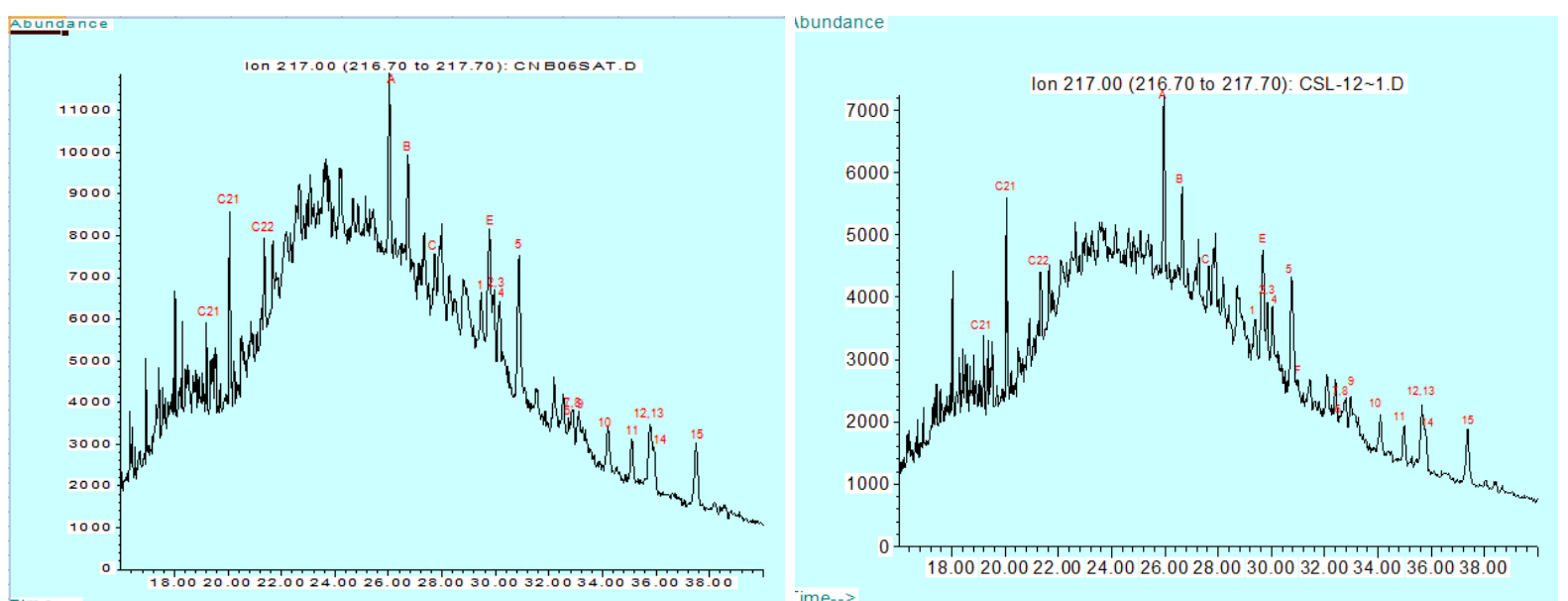

Gambar 5B. Diagram Fragmentogram Massa dari biomarker Steranana (m/z 217) pada Formasi Cinambo daerah Sumedang 


\section{MAKALAH ILMIAH}

\section{Komposisi Sterane dan Lingkungan Pengendapan Batuan Induk}

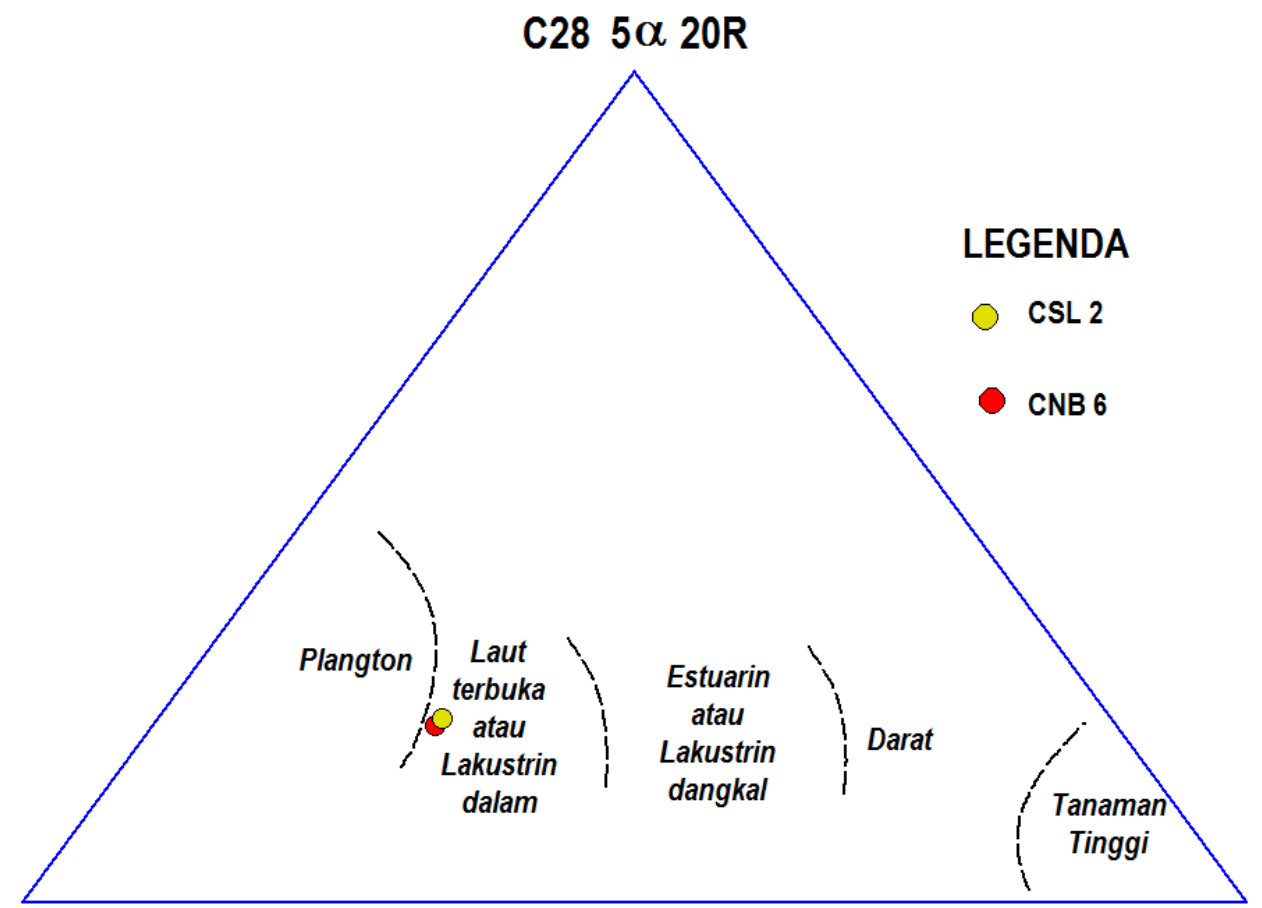

C27 $5 \alpha 20 R$

C29 $5 \propto 20 R$

Huang and Meinschein's (1979)

Gambar 6. Diagram Komposisi sterana dan lingkungan pengendapan batuan induk rembasan minyak di daerah penelitian versi D.W. Waples \& Machihara, (1991)

\section{Korelasi batuan induk dengan rembesan minyak}

Untuk mengetahui korelasi antara batuan induk Formasi Cinambo di wilayah daerah Sumedang dan rembesan minyak Majalengka dilakukan analisis GCMS pada rembesan minyak daerah Majalengka (Praptisih dan Kamtono, 2016) dan 2 percontoh ekstrak batuan dari Formasi Cinambo daerah Sumedang. Hasil analisis GCMS menunjukkan tidak adanya korelasi positif antara batuan induk Formasi Cinambo dengan rembesan minyak di daerah Majalengka. Hal ini ditunjukkan oleh perbedaan asal material organik, yaitu pada rembesan minyak Majalengka berasal dari material darat (Praptisih dan Kamtono, 2016), sedangkan percontoh batuan induk Formasi Cinambo berasal dari material ganggang. Perbedaan yang lain ditunjukkan oleh lingkungan pengendapan asal material organik untuk rembesan minyak berasal dari material yang diendapkan pada lingkungan estuarin atau lakustrin dangkal, sedangkan pada percontoh batuan induk Sumedang berasal dari material yang diendapkan pada laut terbuka atau lakustrin dalam.

\section{KESIMPULAN}

Percontoh batuan induk Formasi Cinambo dari daerah Sumedang dengan nilai TOC $0,32-1,47 \%$ berpotensi rendah hingga baik membentuk hidrokarbon. Material organiknya termasuk kerogen tipe III, tingkat kematangan belum matang hingga matang. Nilai $\mathrm{HI}$ sebesar $2-90 \mathrm{mgHC} / \mathrm{g}$ TOC dapat menghasilkan gas dengan kuantitas kecil dan termasuk dalam gas prone. Berdasarkan percontoh yang dianalisis, batuan induk Formasi Cinambo material organiknya berasal dari material 
ganggang dan diendapkan pada laut terbuka atau danau dalam. Batuan induk Formasi Cinambo di daerah Sumedang tidak mempunyai korelasi positif dengan rembesan minyak di daerah Majalengka.

\section{UCAPAN TERIMAKASIH}

Dengan selesainya makalah ini, penulis mengucapkan terima kasih kepada Kepala Pusat Penelitian Geoteknologi LIPI dan Pejabat Pembuat Komitmen yang telah memberikan kesempatan melakukan penelitian di daerah Sumedang. Ucapan terima kasih ditujukan kepada Sdr. Djoko Trisuksmono dan Sdr. Adde Tatang yang telah membantu dalam pengambilan data di lapangan. Terima kasih juga pada rekan-rekan peneliti atas diskusinya.

\section{DAFTAR PUSTAKA}

Baskin, D. K. (1997). Atomic H/C Ratio of Kerogen as a an Estimate of Thermal Maturity and Organic Matter Conversion. American Association of Petroleum Geologist Bull, 81, 14371450.

Djuri, M. (1995). Peta Geologi Lembar Arjowinangun, Jawa, skala 1: 100.000. Pusat Penelitian dan Pengembangan Geologi.

Hidayat, R. dan F. (2007). Inventarisasi Kandungan Minyak dalam Batuan Daerah Kedungjati, Kabupaten Semarang, Provinsi Jawa Tengah. In Prosiding Pemaparan Hasil Kegiatan Lapangan dan Non Lapangan Pusat Sumberdaya Geologi (p. 13 h).

Hunt, J. M. (1979). Petroleum geochemistry and geology. A Series of Books in Geology, (DI), 617. https://doi.org/10.1016/S0009-2541 (96)00131-3
Mukhopadhyay, P. K., Wade J. A, Gruge, M. A. (1995). Organic facies and maturation of Jurassic/Cretaceous rock, and possible oil-source rock correlation based on pirolysis of asphaltenes, Scotian Basin Canada. Org. Geochem, vol.22, no, 43-55.

Panggabean, H., \& Heryanto, R. (2009). An appraisal for the petroleum source rocks on oil seep and rock samples of the Tertiary Seblat and Lemau Formations, Bengkulu Basin. Indonesian Journal on Geoscience, 4(1), 43-55. Retrieved from http://ijog.bgl.esdm.go.id.

Pramono, W. dan Amijaya, H. (n.d.). Karakteristik geokimia rembesan minyak bumi di daerah Bantal, Kecamatan Bancak, Semarang, Jawa Tengah. In Prosiding Pertemuan IImiah Tahunan IAGI ke 37, Bandung.

Praptisih. (2016). Karakteristik batuan induk hidrokarbon dan hubungannya dengan rembesan minyak di lapangan Cipluk, Kabupaten Kendal, Provinsi Jawa Tengah. Buletin Sumberdaya Geologi Dan Mineral, 11, 27-40.

Praptisih dan Kamtono. (2016). Potensi Batuan Induk Hidrokarbon pada Formasi Cinambo di Daerah Majalengka, Jawa Barat in the Majalengka Area, West Java (Vol. 17).

Price, P. L., O'Sullivan, T. and Alexander, R. (1987). The nature and occurence of oil in Seram, Indonesia. In Procceding of the Indonesian Petroleum Association. Sixteenth Annual Convention, Indonesian Petroleum Association, Jakarta, Indonesia. (pp. 141-73). 


\section{MAKALAH ILMIAH}

Rad, F. K. (1984). Quick Look Source Rock Evaluation by Pyrolysis Technique, 2(Volume 2), 1984.

Waples, D. W. (1985). Geochemistry in petroleum exploration. D. Reidel Publishing Company. https://doi.org/10.1007/978-94-0095436-6.
Waples, D. W., \& , Machihara, T. (1991). Biomarkers for geologists. A practical guide to the application of steranes and triterpanes in petroleum geology. AAPG Methods in Exploration, 9(9), 91. Retrieved from http://search.datapages.com/ data/specpubs/me9.htm.

\begin{tabular}{|ll|}
\hline Diterima & $:$ 30 Agustus 2017 \\
Direvisi & $:$ 06 September 2017 \\
Disetujui & $:$ 29 November 2017 \\
\hline
\end{tabular}

